\title{
EFEKTIVITAS PENERAPAN MALCOLM BALDRIGE CRITERIA DALAM PENINGKATAN PRODUKTIVITAS PT. PJB UP GRESIK
}

\author{
ABDURRAHMAN FARIS INDRIYA HIMAWAN \\ Fakultas Ekonomi, Universitas Muhammadiyah Gresik
}

In this research has purposed for knowing the implementation of increasing productivity Malcolm Baldrige Criteria levels and the influence of increasing productivity in PT PJB UP Gresik. Malcolm Baldrige Criteria that is observed include Leadership, Strategic Planning, Costumer And Market Focus, Measurement Analysis And Knowledge Management, Human Resources Focus, Process Management And Business Result. The implementation of Malcolm Baldrige Criteria in PT PJB UP Gresik had been successes, in this case, it is indicated that has a good effectivness levels, it means that every criteria at Malcolm Baldrige has a good effevtivity of increasing productivity in PT PJB UP Gresik. The assessment of effetivness percentage is according to general by using Malcolm Baldrige Criteria is PT PJB UP Gresik showed the beginning of approach that is systematic in answering the backgrounds of regulations from every criteria items. But there is a big gap that is enough in approaching and deployment in some criterias. Based on the result of multiple linear regression analysis is found that influence of Malcolm Baldrige Criteria's implementation in increasing productivity at PT PJB UP Gresik is according to the simultaneous has influenced that is significant whereas according to the partial only leadership criteria that has possitve influence in increasing productivity of PT PJB UP Gresik, another from that criteria does not have influence that is significant in increasing productivity at PT PJB UP Gresik.

Keywords: Malcolm Baldrige Criteria, Effectivity, Productivity 


\section{PENDAHULUAN}

Daya saing bangsa Indonesia salah satunya tergantung dari daya saing perusahaan - perusahaan, yang pada gilirannya tergantung dari kemampuan dalam menerapkan praktek - praktek terbaik global. Salah satu praktek terbaik yang merupakan kebutuhan dasar dalam upaya mencapai daya saing global adalah keunggulan dalam manajemen mutu dengan demikian perusahaan tidak ada jalan pintas, untuk membangun perusahaan yang produktif dan berdaya saing tinggi, serta mampu bertahan dalam jangka waktu yang lama.

Perusahaan yang produktif memerlukan tumpuan yang kuat, yaitu mutu, baik yang ada di dalam maupun di luar perusahaan yang dapat dirasakan oleh pelanggan dan stakeholder lainnya. Mutu harus berangkat dari budaya, dalam hal ini adalah budaya perusahaan dan budaya kerja. Artinya, dibutuhkan sebuah sistem yang mampu membentuk sebuah budaya, yaitu sebuah kerangka berpikir dan berperilaku yang mengarahkan dan menuntun perusahaan yang produktif serta mampu mencapai sebuah keberhasilan daya saing perusahaan. Tjiptono dan Anastasia (2003) menyatakan komponen-komponen penunjang daya saing suatu perusahaan adalah (1) Standar hidup, (2) Investasi, (3) Produktivitas, dan (4) Perdagangan.

Keberhasilan perusahaan dalam mencapai tujuannya ditentukan oleh fungsi-fungsi manajemen yang terdapat di dalamnya dalam mengelola faktorfaktor yang sangat berpengaruh terhadap kepuasan konsumen dan kinerja perusahaan secara keseluruhan. Ayuningtias (2005) berpendapat bahwa tujuan berdirinya suatu perusahaan adalah mencari keuntungan atau laba, karena jumlah laba yang besar menunjukkan bahwa perusahaan tersebut berhasil, dan sebaliknya jika jumlah laba kecil menunjukkan perusahaan-perusahaan tersebut kurang berhasil. Sebagai mana pendapat Nurdin dan Yasrin (2004) bahwa faktor penting yang mempengaruhi manajemen dan mutu perusahaan adalah produktivitas, artinya meningkatkan produktivitas berarti meningkatkan kesejahteraan dan mutu perusahaan.

Rendahnya produktivitas yang terjadi disebabkan karena aktivitas yang dilakukan oleh perusahaan dalam berproduksi kurang memperhatikan jumlah perbandingan yang seharusnya dipertimbangkan. Atau pemborosan sumber produksi telah terjadi dalam perusahaan tersebut sehingga akan berpengaruh dalam pencapaian laba tidak seperti yang ditargetkan. Produktivitas merupakan hubungan antara hasil nyata (barang-barang atau jasa) dengan sumber daya yang ada, misalnya produktivitas adalah ukuran efisiensi produktif, suatu perbandingan antara input dan output dimana input sering dibatasi dengan sumber daya perusahaan, sedangkan output diukur dalam kesatuan fisik bentuk dan nilai (Sedarmayanti, 2009;56 ).

Sadikin $(2005 ; 17)$ mengemukakan bahwa penerapan sistem manajemen kinerja atau alat bantu pengukuran kinerja seperti International Standart of Organization ( ISO), balance score card, Malcolm Baldrige Criteria dan beberapa alat ukur lainnya yang banyak diterapkan di perusahaan Indonesia tidak akan memberikan hasil yang memuaskan apabila program peningkatan kinerjanya masih dilakukan secara acak atau parsial. Perusahaan Badan Usaha Milik Negara (BUMN) di Indonesia banyak menerapkan pengukuran produktivitas berbasis Malcolm Baldrige Criteria, akan tetapi perusahaan tidak bisa menerapkan secara langsung di lapangan karena penerapannya masih sebatas perhitungan skor dan posisi perusahaan dibanding dengan perusahaan lain di Indonesia maupun Internasional dalam penerapan Malcolm Baldrige Criteria.

Malcolm Baldrige Criteria for Performance Excellence atau yang biasa disebut Malcolm Baldrige Criteria (MBC) adalah suatu pendekatan yang dapat menggambarkan bagaimana suatu perusahaan dapat meningkatkan produktivitas dan efektivitas. MBC merupakan salah satu metode yang terdapat dalam Total Quality Management (TQM) yang telah mampu meningkatkan mutu bersaing untuk perusahaan-perusahaan besar di Amerika. MBC sendiri terdiri dari sebelas tata nilai dan konsep yang digunakan untuk menilai kinerja suatu perusahaan yang bertujuan untuk meningkatkan produktivitas dan efektivitas perusahaan secara keseluruhan.

Malcolm Baldrige Criteria terdiri dari sebelas tata nilai yang diantaranya, Kepemimpian yang visioner, Keunggulan menurut pelanggan, Pemb- 
elajaran perorangan dan organisasional, Menghargai pegawai dan mitra, Kegesitan, Fokus kepada masa depan, Mengelola inovasi, Manajemen berdasarkan fakta, Pertanggungjawaban social, Fokus kepada hasil dan penciptaan nilai, dan Persepektif Kesisteman. Tata nilai dan konsep Baldrige pada ujungnya akan bermuara di dalam tujuh Kriteria Malcolm Baldrige yang terdiri dari (1) Kepemimpinan (Leadership), (2) Perencanaan strategis (Strategic Planning), (3) Fokus pelanggan dan pasar (Costumer\&Market Focus), (4) Pengukuran, Analisis dan Manajemen pengetahuan (Measurement, Analysis and Knowledge Management), (5) Fokus SDM (Human Resources Focus), (6) Manajemen proses (Process Management), dan (7) Hasil bisnis (Business Result).

Sejak tahun 2008 PT. Pembangkitan Jawa Bali Unit Pembangkitan Gresik (PT. PJB UP Gresik ) telah mengaplikasikan Malcolm Baldrige Criteria dalam pengukuran produktivitas dan efektivitas perusahaan, hal ini sejalan dengan induk dari perusahaan ini dimana PT. PLN (persero) telah mengadopsi Malcolm Baldrige Criteria sejak tahun 2003 dalam palaksanaan roda organisasi perusahaan. PT. PJB UP Gresik sendiri merupakan salah satu perusahaan besar yang ada di Indonesia khususnya di Kota Gresik, PT.PJB UP Gresik merupakan perusahaan yang bergerak di bidang produksi listrik. PT. PJB UP Gresik merupakan salah satu unit pembangkitan PT.PJB, dimana perusahaan ini anak perusahaan milik PT. PLN (persero) dengan tujuan berdiri melaksanakan desentralisasi, menigkatkan efisiensi, meningkatkan pelayanan kepada masyarakat, dan mampu berkembang secara mandiri. Dapat dilihat pada gambar 1.1 bahwa PT. PJB UP Gresik merupakan produsen listrik besar di Jawa Timur dan sebagai pemasok listrik di Jawa Timur tertinggi yakni 68\% sedangkan di Jawa-Bali 10\% dari total pemasokan listrik. Berdasarkan latar belakang diatas maka rumusan masalah dalam penelitian ini adalah :

Bagaimana efektivitas penerapan Malcolm Baldrige Criteria (MBC) pada PT PJB UP Gresik?

Bagaimana pengaruh penerapan Malcolm Baldrige Criteria (MBC) dalam peningkatan produktivitas PT PJB UP Gresik?

\section{METODE PENELITIAN}

Jenis penelitian ini adalah penelitian deskriptif yang bersifat regresional yaitu meneliti seberapa besar kontribusi atau pengaruh variabel bebas (Independent Variable) terhadap variabel terikatnya (Dependent Variable) dengan menggunakan permasalahan yang ada. Natsir (1988;33) berpendapat bahwa penelitian deskriptif adalah penelitian yang dilakukan dengan cara membuat deskripsi secara sistematis, faktual dan akurat mengenai fakta-fakta, sifat-sifat dan fenomena yang diselidiki. Penelitian ini dilakukan di PT PJB UP Gresik terletak di Jl. Harun Tohir Gresik - Jawa Timur 61112.

Populasi dalam penelitian ini adalah karyawan tetap tiap fungsional dan departemen yang terdapat di PT. PJB UP Gresik. Adapun teknik pengambilan sampel yang digunakan Proportionate Stratified Random Sampling. Menurut Suliyanto (2006;125) Proportionate Stratified Random Sampling adalah teknik yang digunakan bila populasi mempunyai anggota/unsur yang tidak homogen dan berstrata secara proporsional. Pada penelitian ini jumlah sampel yang diambil sejumlah 82 responden.dimana dalam pelaksanaan pengambilan sampel akan diambil sesuai dengan tingkatan manajerial jabatan meliputi manajer, assistant, superviser dan analist/officer/enjiner.

Teknik analisis data yang digunakan dalam penelitian ini adalah Analisa deskriptif ini digunakan untuk menjawab tingkat efektivitas penerapan Malcolm Baldrige Criteria di PT PJB UP Gresik. Untuk menentukan tingkat efektivitas bisa diketahui melalui pendistribusian hasil kuisioner pada setiap tingkatan manajerial, kemudian di analisis dan ditarik suatu kesimpulan. Sedangkan untuk mengetahui pengaruh Malcolm Baldrige Criteria terhadap mendorong peningkatan produktivitas PT PJB UP Gresik menggunakan model regresi linier berganda.

$Y=a+b_{1} x_{1}+b_{2} x_{2}+b_{3} x_{3}+b_{4} x_{4}+b_{5} x_{5}+b_{6} x_{6}+b_{7} x_{7}$

Dimana :

$\mathrm{Y}=$ Produktivitas Perusahaan

$\mathrm{a}=$ Konstanta

$\mathrm{X}_{1}=$ Leadership

$\mathrm{X}_{2}=$ Strategic Planning 
$\mathrm{X}_{3}=$ Costumer and Market Focus

$\mathrm{X}_{4}=$ Measurement, Analysis and

Knowledge Management

$\mathrm{X}_{5}=$ Human Resorce Focus

$\mathrm{X}_{6}=$ Process Management

$\mathrm{X}_{7}=$ Bussiness Result

\section{HASIL DAN PEMBAHASAN}

\section{Analisis Efektivitas Penerapan Malcolm Bald-} rige Criteria

Pada penelitian ini tingkat efektivitas penerapan Malcolm Baldrige Criteria ditentukan melalui teknik analisis distribusi frekwensi dan kemudian di deskripsikan untuk mengetahui keefektivitasan tiap variabel atau tiap kriteria. Berikut ini akan disajikan hasil analisis tiap tabel variabel.

Berdasarkan analisis data yang telah diuraikan, hasil pengujian dengan menghitung prosentase tingkat efektivitas penerapan Malcolm Baldrige Criteria diperoleh bahwa setiap kriteria memiliki tingkat efektivitas yang baik, hal ini membuktikan bahwa PT PJB UP Gresik telah memiliki komitmen dalam penerapan Malcolm Baldrige Criteria pada setiap lini manajemen perusahaan. Gaspersz $(2007 ; 24)$ upaya peningkatan kualitas dan kuantitas produk dari perusahaan harus dimulai dari komitmen yang tinggi dari manajemen disertai dengan peningkatan produktivitas individu yang ada dalam perusahaan itu.

Tingkat prosentase efektivitas kriteria leadership memiliki nilai $68,1 \%$, hal ini mengindikasikan bahwa pemimpin yang ada di setiap lini manajemen PT PJB UP Gresik telah menjalankan tugasnya dengan baik, terbukti bahwa 70,3\% pemimpin telah menciptakan pencapaian visi serta $66,3 \%$ pemimpin telah melibatkan karyawan dalam pengambilan keputusan. Welch (2004;54) berpendapat bahwa seorang pemimpin harus menciptakan visi dan menyalakan atau menbakar semangat organisasi agar membuat visi itu menjadi kenyataan, dalam bukunya Welch $(2004 ; 58)$ juga mengemukakan bahwa seorang pemimpin yang berkualitas adalah pemimpin yang melibatkan setiap orang danmenyambut ide besar dari mana saja artinya setiap orang untuk berkontribusi adalah datang dengan ide terbaik.

Selanjutnya, tingkat prosentase efektivitas kriteria strategic planning memiliki nilai $65,6 \%$, hal ini dinilai efektif dalam penerapannya di PT PJB UP Gresik. Pada kriteria ini dimensi yang paling unggul adalah menciptakan keunggulan strategis dan penentuan strategi kunci dengan nilai prosentase $68,94 \%$ dan $67,53 \%$ artinya PT PJB UP Gresik telah membuat rencana strategis dalam jangka pendek dan jangka panjang kemudian mengkomunikasikan rencana kepada semua level pegawai sehingga mereka memahami perannya dalam membantu perusahaan mencapai visi. Gasperz $(2007 ; 270)$ berpendapat bahwa perencanaan strategis merupakan suatu upaya mengidentifikasi hasil kinerja yang diinginkan dimasa depan, indikator-indikator kinerja kunci dan program-program peningkatan keunggulan kinerja yang harus dilaksanakan agar mencapai hasil yang diinginkan.

Tingkat prosentase efektivitas kriteria costumer \& market focus memiliki nilai yang efektif yakni $66,9 \%$ hal ini dibuktikan dari perusahaan telah mengidentifikasi pelanggan dan pasar dengan nilai prosentase $69,41 \%$ selain itu PT PJB UP Gresik juga telah membangun komunikasi bisnis dengan pelanggan dan pasar sehingga proses bisnis berjalan dengan baik, pada dimensi ini nilai prosentase sebesar $66,35 \%$. Fokus pelanggan dan pasar yang ada menunjukan telah adanya pengatahuan terhadap pelanggan dan pasar sehingga dapat membangun hubungan terhadap pelanggan termasuk didalamnya penanganan terhadap keluhan pelanggan dan juga adanya pendekatan terhadap penentuan kepuasan pelanggan pada perusahaan.

Penghitungan tingkat prosentase efektivitas selanjutnya adalah kriteria measurement, analysis \& knowledge management, pada kriteria ini nilai efektivitas sebesar $68,12 \%$ hal ini dibuktikan bahwa PT PJB UP Gresik telah melakukan pengukuran produktivitas dan melakukan analisis produktivitas secara berkesinambungan dapat dilihat dengan nilai prosentase yang tinggi yakni sebesar 68,47\% dan 68,71\%. PT PJB UP Gresik juga telah melakukan pengelolaan teknologi in formasi dengan dibuktikannya saat ini perusahaan selalu meng-up date data secara baik selain itu perusahaan juga telah menggunakan informasi sebagai bahan pertimbangan dalam pengambilan keputusan. 
Tabel 1

Efektivitas Kriteria Leadership

\begin{tabular}{|c|c|c|c|c|c|c|c|c|c|c|c|c|}
\hline \multirow{3}{*}{ No. } & \multirow{3}{*}{ Pertanyaan } & \multicolumn{10}{|c|}{$\begin{array}{c}\text { TANGGAPAN RESPONDEN MENGENAI EFEKTIVITAS MALCOLM } \\
\text { BALDRIGE CRITERIA }\end{array}$} & \multirow{3}{*}{$\begin{array}{l}\text { Prosentasi } \\
\text { Efektivitas } \\
\%\end{array}$} \\
\hline & & \multicolumn{2}{|c|}{0} & \multicolumn{2}{|c|}{ TS (1) } & \multicolumn{2}{|c|}{ KS (2) } & \multicolumn{2}{|c|}{$S(3)$} & \multicolumn{2}{|c|}{ SS (4) } & \\
\hline & & $f$ & $\%$ & $f$ & $\%$ & $f$ & $\%$ & $f$ & $\%$ & $f$ & $\%$ & \\
\hline 1 & Penetapan Visi & 0 & 0 & 0 & 0 & 1 & 1,2 & 30 & 36,6 & 51 & 62,2 & 69,6 \\
\hline 2 & Penyebarluasan Visi & 0 & 0 & 0 & 0 & 1 & 1,2 & 46 & 56,1 & 35 & 42,7 & 65,8 \\
\hline 3 & $\begin{array}{l}\text { Menciptakan pencapaian } \\
\text { Visi }\end{array}$ & 0 & 0 & 0 & 0 & 1 & 1,2 & 27 & 32,9 & 54 & 65,9 & 70,3 \\
\hline 4 & $\begin{array}{l}\text { Melibatkan Karyawan } \\
\text { Dalam Keputusan }\end{array}$ & 0 & 0 & 0 & 0 & 4 & 4,9 & 38 & 46,3 & 40 & 48,8 & 66,3 \\
\hline \multicolumn{12}{|c|}{ Rata-Rata } & 68,1 \\
\hline
\end{tabular}

Tabel 2

Efektivitas Kriteria Strategic Planning

\begin{tabular}{|c|c|c|c|c|c|c|c|c|c|c|c|c|}
\hline \multirow{3}{*}{ No. } & \multirow{3}{*}{ Pertanyaan } & \multicolumn{10}{|c|}{$\begin{array}{l}\text { TANGGAPAN RESPONDEN MENGENAI EFEKTIVITAS MALCOLM } \\
\text { BALDRIGE CRITERIA }\end{array}$} & \multirow{3}{*}{$\begin{array}{c}\text { Prosentasi } \\
\text { Efektivitas } \\
\%\end{array}$} \\
\hline & & \multicolumn{2}{|c|}{0} & \multicolumn{2}{|c|}{ TS (1) } & \multicolumn{2}{|c|}{ KS (2) } & \multicolumn{2}{|c|}{$S(3)$} & \multicolumn{2}{|c|}{ ss(4) } & \\
\hline & & $f$ & $\%$ & $f$ & $\%$ & f & $\%$ & $f$ & $\%$ & $f$ & $\%$ & \\
\hline 1 & $\begin{array}{l}\text { Menciptakan Keunggulan } \\
\text { Strategis }\end{array}$ & 0 & 0 & 0 & 0 & 0 & 0 & 35 & 42,7 & 47 & 57,3 & 68,94 \\
\hline 2 & $\begin{array}{l}\text { Mempertimbangkan } \\
\text { Informasi }\end{array}$ & 0 & 0 & 0 & 0 & 3 & 3,7 & 46 & 56,1 & 33 & 40,2 & 64,94 \\
\hline 3 & $\begin{array}{l}\text { Menentukan Strategi } \\
\text { Kunci }\end{array}$ & 0 & 0 & 0 & 0 & 6 & 7,3 & 29 & 35,4 & 47 & 57,3 & 67,53 \\
\hline 4 & $\begin{array}{l}\text { Mengembangkan } \\
\text { Rencana Kunci }\end{array}$ & 0 & 0 & 0 & 0 & 1 & 1,2 & 67 & 81,7 & 14 & 17,1 & 60,94 \\
\hline \multicolumn{12}{|c|}{ Rata-Rata } & 65,6 \\
\hline
\end{tabular}

Tabel 3

Efektivitas Kriteria Costumer \& Market Fokus

\begin{tabular}{|c|c|c|c|c|c|c|c|c|c|c|c|c|}
\hline \multirow{3}{*}{ No. } & \multirow{3}{*}{ Pertanyaan } & \multicolumn{10}{|c|}{$\begin{array}{l}\text { TANGGAPAN RESPONDEN MENGENAI EFEKTIVITAS MALCOLM } \\
\text { BALDRIGE CRITERIA }\end{array}$} & \multirow{3}{*}{$\begin{array}{c}\text { Prosentasi } \\
\text { Efektivitas } \\
\%\end{array}$} \\
\hline & & \multicolumn{2}{|c|}{0} & \multicolumn{2}{|c|}{ TS (1) } & \multicolumn{2}{|c|}{ KS (2) } & \multicolumn{2}{|c|}{ S (3) } & \multicolumn{2}{|c|}{ SS(4) } & \\
\hline & & f & $\%$ & f & $\%$ & f & $\%$ & $f$ & $\%$ & f & $\%$ & \\
\hline 1 & $\begin{array}{l}\text { Mengidentifikasi } \\
\text { Pelanggan dan Pasar }\end{array}$ & 0 & 0 & 0 & 0 & 1 & 1,2 & 31 & 37,8 & 50 & 61 & 69,41 \\
\hline 2 & Menentukan Kebutuhan & 0 & 0 & 0 & 0 & 1 & 1,2 & 45 & 54,9 & 36 & 43,9 & 66,12 \\
\hline 3 & Membangun Komunikasi & 0 & 0 & 0 & 0 & 2 & 2,4 & 42 & 51,2 & 38 & 46,3 & 66,35 \\
\hline 4 & $\begin{array}{l}\text { Menindak Lanjuti } \\
\text { Keluhan }\end{array}$ & 0 & 0 & 0 & 0 & 0 & 0 & 48 & 58,5 & 34 & 41,5 & 65,88 \\
\hline \multicolumn{12}{|c|}{ Rata-Rata } & 66,9 \\
\hline
\end{tabular}

Tabel 4

Efektivitas Kriteria Measurement, Analysis \& Knowledge Management (MAKM)

\begin{tabular}{|c|c|c|c|c|c|c|c|c|c|c|c|c|}
\hline \multirow{3}{*}{ No. } & \multirow{3}{*}{ Pertanyaan } & \multicolumn{10}{|c|}{$\begin{array}{l}\text { TANGGAPAN RESPONDEN MENGENAI EFEKTIVITAS MALCOLM } \\
\text { BALDRIGE CRITERIA }\end{array}$} & \multirow{3}{*}{$\begin{array}{c}\text { Prosentasi } \\
\text { Efektivitas } \\
\%\end{array}$} \\
\hline & & \multicolumn{2}{|c|}{0} & \multicolumn{2}{|c|}{ TS (1) } & \multicolumn{2}{|c|}{ KS (2) } & \multicolumn{2}{|c|}{$S(3)$} & \multicolumn{2}{|c|}{ SS(4) } & \\
\hline & & $f$ & $\%$ & $f$ & $\%$ & $f$ & $\%$ & $f$ & $\%$ & $f$ & $\%$ & \\
\hline 1 & $\begin{array}{l}\text { Kemudahan } \\
\text { Mendapatkan Informasi }\end{array}$ & 0 & 0 & 0 & 0 & 0 & 0 & 40 & 48,8 & 42 & 51,2 & 67,76 \\
\hline 2 & $\begin{array}{l}\text { Menggunakan Data } \\
\text { Dalam Keputusan }\end{array}$ & 0 & 0 & 0 & 0 & 0 & 0 & 41 & 50 & 41 & 50 & 67,53 \\
\hline 3 & $\begin{array}{l}\text { Menentukan } \\
\text { Pengukuran } \\
\text { Produktivitas }\end{array}$ & 0 & 0 & 0 & 0 & 1 & 1,2 & 35 & 42,7 & 46 & 56,1 & 68,47 \\
\hline 4 & $\begin{array}{l}\text { Melakukan Analisis } \\
\text { Produktivitas }\end{array}$ & 0 & 0 & 0 & 0 & 1 & 1,2 & 34 & 41,5 & 47 & 57,3 & 68,71 \\
\hline & & & & & $a-R a$ & & & & & & & 68,12 \\
\hline
\end{tabular}


Tabel 5

Efektivitas Kriteria Human Resources Focus

\begin{tabular}{|c|c|c|c|c|c|c|c|c|c|c|c|c|}
\hline \multirow{3}{*}{ No. } & \multirow{3}{*}{ Pertanyaan } & \multicolumn{10}{|c|}{$\begin{array}{l}\text { TANGGAPAN RESPONDEN MENGENAI EFEKTIVITAS MALCOLM } \\
\text { BALDRIGE CRITERIA }\end{array}$} & \multirow{3}{*}{$\begin{array}{c}\text { Prosentasi } \\
\text { Efektivitas } \\
\%\end{array}$} \\
\hline & & \multicolumn{2}{|c|}{0} & \multicolumn{2}{|c|}{ TS (1) } & \multicolumn{2}{|c|}{ KS (2) } & \multicolumn{2}{|c|}{$S(3)$} & \multicolumn{2}{|c|}{ SS(4) } & \\
\hline & & $f$ & $\%$ & f & $\%$ & $f$ & $\%$ & $f$ & $\%$ & $f$ & $\%$ & \\
\hline 1 & $\begin{array}{l}\text { Penerapan Rencana di } \\
\text { SDM }\end{array}$ & 0 & 0 & 0 & 0 & 3 & 3,7 & 32 & 39 & 47 & 57,3 & 68,24 \\
\hline 2 & $\begin{array}{l}\text { Pengembangan } \\
\text { Keterlibatan Karyawan }\end{array}$ & 0 & 0 & 8 & 9,8 & 40 & 48,8 & 14 & 17,1 & 20 & 24,4 & 49,41 \\
\hline 3 & $\begin{array}{l}\text { Meningkatkan } \\
\text { Kompetensi Karyawan }\end{array}$ & 0 & 0 & 1 & 1,2 & 3 & 3,7 & 44 & 53,7 & 34 & 41,5 & 64,71 \\
\hline 4 & $\begin{array}{l}\text { Merencanakan } \\
\text { Penjaminan K3 }\end{array}$ & 0 & 0 & 0 & 0 & 5 & 6,1 & 32 & 34 & 45 & 54,1 & 67,29 \\
\hline \multicolumn{12}{|c|}{ Rata-Rata } & 62,41 \\
\hline
\end{tabular}

Tabel 6

Efektivitas Kriteria Process Management

\begin{tabular}{|c|c|c|c|c|c|c|c|c|c|c|c|c|}
\hline \multirow{3}{*}{ No. } & \multirow{3}{*}{ Pertanyaan } & \multicolumn{10}{|c|}{$\begin{array}{l}\text { TANGGAPAN RESPONDEN MENGENAI EFEKTIVITAS MALCOLM } \\
\text { BALDRIGE CRITERIA }\end{array}$} & \multirow{3}{*}{$\begin{array}{c}\text { Prosentasi } \\
\text { Efektivitas } \\
\%\end{array}$} \\
\hline & & \multicolumn{2}{|c|}{0} & \multicolumn{2}{|c|}{ TS (1) } & \multicolumn{2}{|c|}{ KS (2) } & \multicolumn{2}{|c|}{$S(3)$} & \multicolumn{2}{|c|}{ SS(4) } & \\
\hline & & $f$ & $\%$ & $f$ & $\%$ & $f$ & $\%$ & $f$ & $\%$ & $f$ & $\%$ & \\
\hline 1 & $\begin{array}{l}\text { Peningkatan Proses } \\
\text { Produksi }\end{array}$ & 0 & 0 & 0 & 0 & 1 & 1,2 & 43 & 52,4 & 38 & 46,3 & 66,59 \\
\hline 2 & $\begin{array}{l}\text { Menetapkan Proses } \\
\text { Bisnis Kunci }\end{array}$ & 0 & 0 & 0 & 0 & 3 & 3,7 & 34 & 41,5 & 45 & 54,9 & 67,76 \\
\hline 3 & $\begin{array}{l}\text { Menjamin Kesiapan } \\
\text { Sistem Kerja }\end{array}$ & 0 & 0 & 0 & 0 & 0 & 0 & 37 & 45,1 & 45 & 54,9 & 68,47 \\
\hline 4 & $\begin{array}{l}\text { Melakukan Inovasi } \\
\text { Sistem Kerja }\end{array}$ & 0 & 0 & 0 & 0 & 0 & 0 & 37 & 45,1 & 45 & 54,9 & 68,47 \\
\hline \multicolumn{12}{|c|}{ Rata-Rata } & 67,82 \\
\hline
\end{tabular}

Tabel 7

Efektivitas Kriteria Bussiness Result

\begin{tabular}{|c|c|c|c|c|c|c|c|c|c|c|c|c|}
\hline \multirow{3}{*}{ No. } & \multirow{3}{*}{ Pertanyaan } & \multicolumn{10}{|c|}{$\begin{array}{l}\text { TANGGAPAN RESPONDEN MENGENAI EFEKTIVITAS MALCOLM } \\
\text { BALDRIGE CRITERIA }\end{array}$} & \multirow{3}{*}{$\begin{array}{c}\text { Prosentasi } \\
\text { Efektivitas } \\
\%\end{array}$} \\
\hline & & \multicolumn{2}{|c|}{0} & \multicolumn{2}{|c|}{ TS (1) } & \multicolumn{2}{|c|}{ KS (2) } & \multicolumn{2}{|c|}{$S(3)$} & \multicolumn{2}{|c|}{ ss(4) } & \\
\hline & & $f$ & $\%$ & $f$ & $\%$ & $f$ & $\%$ & $f$ & $\%$ & $f$ & $\%$ & \\
\hline 1 & $\begin{array}{l}\text { Menentukan Indikator } \\
\text { Kepuasan Pelanggan }\end{array}$ & 0 & 0 & 0 & 0 & 0 & 0 & 37 & 45,1 & 45 & 54,9 & 68,47 \\
\hline 2 & $\begin{array}{l}\text { Menentukan Indikator } \\
\text { Operasional Sistem Kerja }\end{array}$ & 0 & 0 & 0 & 0 & 0 & 0 & 32 & 39 & 50 & 61 & 69,65 \\
\hline 3 & $\begin{array}{l}\text { Menentukan Indikator } \\
\text { Keterlibatan Karyawan }\end{array}$ & 0 & 0 & 0 & 0 & 0 & 0 & 36 & 43,9 & 46 & 56,1 & 68,71 \\
\hline 4 & $\begin{array}{l}\text { Menentukan Indikator Sistem } \\
\text { Kerja }\end{array}$ & 0 & 0 & 0 & 0 & 1 & 1,2 & 44 & 53,7 & 37 & 45,1 & 66,35 \\
\hline \multicolumn{12}{|c|}{ Rata-Rata } & 68,29 \\
\hline
\end{tabular}


Gaspersz (2007;317) mengemukakan bahwa pengukuran dan penganalisisas memainkan peranan yang sangat penting bagi peningkatan suatu kemajuan kearah yang lebih baik bagi perusahaan. Dalam manajemen kualitas, pengukuran terhadap fakta-fakta akan menghasilkan data yang kemudian apabila data tersebut dianalisis secara tepat akan memberikan informasi yang akurat, selanjutnya informasi itu akan berguna bagi perusahaan untuk peningkatan pengetahuan dalam pengambilan keputusan.

Selanjutnya, tingkat prosentase efektivitas yang dinilai adalah kriteria human resources focus, pada kriteria ini tingkat efektivitas sebesar $62,41 \%$ hal ini didukung oleh sudah diterapkannya perencanaan di SDM serta telah ditingkatkannya kompetensi karywan sehingga perusahaan memiliki karyawan yang berkapasitas dan memiliki kapabilitas. Pada dimensi perencanaan rencana di SDM nilai tingkat efektivitasnya mencapai 68,24\%. PT PJB UP Gresik telah merencanakan penjaminan Keselamatan Kerja Karyawan (K3) hal ini dibuktikan bahwa dimensi ini menyumbang prosentase yang tinggi dengan nilai 67,29\% dalam keterlibatan karyawan, PT PJB UP Gresik juga telah melakukan pengembangan secara berkesinambungan.

Welch $(2004 ; 103)$ berpendapat manajemen organisasi perlu melibatkan karyawan melalui menetapkan tim-tim peningkatan kinerja yang memiliki pengetahuan dari proses, serta memberikan pelatihan yang diperlukan agar menjamin keterampilan yang dimiliki dalam perbaikan proses. Efektivitas dari implementasi program-program peningkatan kompetensi dan kapabilitas karyawan di perusahaan akan sangat tergantung pada pelaksanaan secara tepat dari perana stakeholders dan semua lini manajemen.

Tingkat prosentase efektivitas yang dinilai selanjutnya adalah kriteria process management, pada kriteria ini tingkat efektivitasanya mencapai $67,82 \%$, nilai yang efektif dalam kontribusi efektivitas penerapan Malcolm Baldrige Criteria di PT PJB UP Gresik, hal ini bisa dibuktikan dari dimensi yang ada bahwa hampir tiap dimensi memiliki tingkat efektivitas yang tinggi. PT PJB UP Gresik telah meningkatkan proses produksi dan telah menetapkan proses kunci sehingga dalam aktivitas kerja para karyawan dituntut untuk melakukan inovasi dalam sistem kerja dalam dimensi ini nilai prosentasenya berturut-turut sebesar $66,59 \%$ dan $67,76 \%$. Untuk menjamin proses produksi berjalan lancar PT PJB UP Gresik telah menjamin kesiapan sistem kerja hal ini dilakukan agar mampu menghadapi keadaan-keadaan darurat atau bencana melalui memperhatikan pencegahan, manajemen, kontinuitas, operasional dan pemulihan (recovery) pada dimensi ini tingkat efektivitasannya mencapai $68,47 \%$.

Terakhir, tingkat efektivitas yang dinilai adalah kriteria business result, kriteria ini merupakan hasil dari keseluruhan kriteria yang dinilai pada penerapan Malcolm Baldrige Criteria. Pada kriteria ini dianggap paling penting karena dalam penerapan Malcolm Baldrige Criteria di perusahaan business result memiliki kontribusi yang besar dalam sistem scoring examiner, dalam berbagai masalah yang terjadi di perusahaan saat examiner kriteria ini menjadi batu sandungan dalam memperoleh skor Malcolm Baldrige Criteria (Sadikin.2005;54). Dari hasil penilaian tingkat efektivitas penerapan Malcolm Baldrige Criteria di PT PJB UP Gresik, kriteria ini memilliki tingkat efektivitas dengan nilai 68,29\%. Hal ini bisa dibuktikan bahwa PT PJB UP Gresik telah menentukan indikator-indikator dalam menentukan hasil bisnis, diantaranya perusahaan telah menentukan indikator kepuasan pelanggan yang berkontribusi nilai sebesar $68,47 \%$ selanjutnya indikator operasional sistem kerja, indikator keterlibatan karyawan dan indikator sistem kerja dengan nilai efektivitas berturut-turut sebesar $69,65 \%, 68,71 \%$ dan $66,35 \%$.

\section{Analisis Malcolm Baldrige Criteria dalam Peningkatan Produktivitas.}

Analisis regresi linear adalah analisis hubungan antara variabel dependen (Y) dengan variabel independen (X), jika menggunakan dua atau lebih variabel independen dalam satu model regresi maka disebut analisis regresi linea berganda. Pada penelitian ini variabel dependen (Y) adalah produktivitas sedangkan untuk variabel independennya adalah leadership (X1), strategic planning (X2), costumer \& market focus (X3), MAKM (X4), human resources focus (X5), process man- 
agement (X6) dan business result (X7).

Dari hasil analisis seperti tabel 9 pada diperoleh persamaan fungsi regresi linear berganda sebagai berikut :

$$
\begin{aligned}
Y= & 2,439+0,402 X_{1}-0,050 X_{2}+0,341 X_{3}+0,212 X_{4}+ \\
& 0,108 X_{5}+0,101 X_{6}+0,223 X_{7}
\end{aligned}
$$

a. Jika $X_{1}$ berubah dengan satu satuan maka $Y$ akan berubah sebesar 0,402 dengan anggapan $\mathrm{X}_{2}, \mathrm{X}_{3}, \mathrm{X}_{4}, \mathrm{X}_{5}, \mathrm{X}_{6}$, dan $\mathrm{X}_{7}$ tetap artinya semakin baik kriteria leadership yang dilakukan oleh perusahaan maka produktivitas meningkat sebesar 40,2\% dengan menganggap variabel lain tetap atau konstan.

b. Jika $\mathrm{X}_{2}$ berubah dengan satu satuan maka $\mathrm{Y}$ akan berubah sebesar -0,050 dengan anggapan $X_{1}, X_{3}, X_{4}, X_{5}, X_{6}$, dan $X_{7}$ tetap artinya jika kriteria strategic planning yang dilakukan oleh perusahaan maka produktivitas menurun sebesar 5\% dengan menganggap variabel lain tetap atau konstan.

c. Jika $\mathrm{X}_{3}$ berubah dengan satu satuan maka $\mathrm{Y}$ akan berubah sebesar 0,341 dengan anggapan $\mathrm{X}_{1}, \mathrm{X}_{2}, \mathrm{X}_{4}, \mathrm{X}_{5}, \mathrm{X}_{6}$, dan $\mathrm{X}_{7}$ tetap artinya semakin baik kriteria costumer and market focus yang dilakukan oleh perusahaan maka produktivitas meningkat sebesar 34,1\% dengan menganggap variabel lain tetap atau konstan.

d. Jika $\mathrm{X}_{4}$ berubah dengan satu satuan maka $\mathrm{Y}$ akan berubah sebesar 0,212 dengan anggapan $X_{1}, X_{2}, X_{3}, X_{5}, X_{6}$, dan $X_{7}$ tetap artinya semakin baik kriteria measurement, analysis, and knowledge management yang dilakukan oleh perusahaan maka produktivitas meningkat sebesar 21,2\% dengan menganggap variabel lain tetap atau konstan.

e. Jika $\mathrm{X}_{5}$ berubah dengan satu satuan maka $\mathrm{Y}$ akan berubah sebesar 0,108 dengan anggapan $\mathrm{X}_{1}, \mathrm{X}_{2}, \mathrm{X}_{3}, \mathrm{X}_{4}, \mathrm{X}_{6}$, dan $\mathrm{X}_{7}$ tetap artinya semakin baik kriteria human resources focus yang dilakukan oleh perusahaan maka produktivitas meningkat sebesar 10,8\% dengan menganggap variabel lain tetap atau konstan.

f. Jika $X_{6}$ berubah dengan satu satuan maka $Y$ akan berubah sebesar 0,101 dengan anggapan $\mathrm{X}_{1}, \mathrm{X}_{2}, \mathrm{X}_{3}, \mathrm{X}_{4}, \mathrm{X}_{5}$, dan $\mathrm{X}_{7}$ tetap artinya semakin baik kriteria process management yang dilakukan oleh perusahaan maka produktivitas meningkat sebesar 10,1\% dengan menganggap variabel lain tetap atau konstan.

g. Jika $\mathrm{X}_{7}$ berubah dengan satu satuan maka Y akan berubah sebesar 0,223 dengan anggapan $\mathrm{X}_{1}, \mathrm{X}_{2}, \mathrm{X}_{3}, \mathrm{X}_{4}, \mathrm{X}_{5}$, dan $\mathrm{X}_{6}$ tetap artinya semakin baik kriteria business result yang dilakukan oleh perusahaan maka produktivitas meningkat sebesar 22,3\% dengan menganggap variabel lain tetap atau konstan.

Tabel 8

Model Summary

\begin{tabular}{lcrrr}
\hline Model & $\mathbf{R}$ & $\begin{array}{c}\mathbf{R} \\
\text { Square }\end{array}$ & $\begin{array}{c}\text { Adjusted R } \\
\text { Square }\end{array}$ & $\begin{array}{c}\text { Std. Error } \\
\text { of the } \\
\text { Estimate }\end{array}$ \\
\hline 1 &, $686(\mathrm{a})$ &, 471 &, 421 & 1,678 \\
\hline
\end{tabular}

Analisis $\mathrm{R}^{2}$ ( R Square ) atau koefisien determinasi digunakan untuk mengetahui seberapa besar prosentasi sumbangan pengaruh variabel independen secara bersama-sama terhadap variabel dependen. Pada tabel 4.22 tabel model summary dapat diketahui bahwa bilai $\mathrm{R}^{2}$ ( $\mathrm{R}$ Square) adalah 0,421 , artinya sumbangan pengaruh dari variabel independen yaitu 42,1\% sedangkan sisanya sebesar $57,9 \%$ dipengaruhi oleh faktor lain yang tidak diteliti.

\section{Uji t (Uji Parsial)}

Uji t digunakan untuk menguji pengaruh variabel independen (X) secara parsial atau berpengaruh secara masing-masing terhadap variabel dependen $(Y)$, dengan menggunakan tingkat signifikansi 0,05: $2=0,025$ (Uji dua sisi), $\mathrm{df}=\mathrm{n}-\mathrm{k}-1$ atau 82-7-1 $=74$, maka didapatkan $\mathrm{t}$ tabel sebesar 1,998. Untuk pengambilan keputusan pada uji $\mathrm{t}$ adalah :

- $\quad \mathrm{t}$ hitung $\leq \mathrm{t}$ tabel atau $-\mathrm{t}$ hitung $\geq-\mathrm{t}$ tabel jadi $\mathrm{H}_{0}$ diterima

- $\quad \mathrm{t}$ hitung $>\mathrm{t}$ tabel atau $-\mathrm{t}$ hitung $<-\mathrm{t}$ tabel jadi $\mathrm{H}_{0}$ ditolak

Untuk menguji hipotesis pengaruh secara parsial pada penelitian ini akan disajikan berikut dibawah ini :

\section{Leadership $\left(\mathrm{X}_{1}\right)$}

Berdasarkan perhitungan diperoleh $\mathrm{t}$ hitung sebesar 2,143 lebih besar dari $t$ tabel sebesar 1,998. Dapat diketahui bahwa $\mathrm{t}$ hitung $>\mathrm{t}$ tabel 
Tabel 9

Hasil Regresi

\begin{tabular}{llrrrrrr}
\hline \multirow{2}{*}{ Model } & & \multicolumn{2}{c}{$\begin{array}{c}\text { Unstandardized } \\
\text { Coefficients }\end{array}$} & $\begin{array}{c}\text { Standardized } \\
\text { Coefficients }\end{array}$ & t & Sig. \\
\cline { 3 - 5 } & & \multicolumn{2}{c}{ B } & Std. Error & Beta & & \\
\hline 1 & (Constant) & 2,439 & 2,494 & & &, 978 &, 331 \\
& Leadership &, 402 &, 187 &, 267 & 2,143 &, 035 \\
& Strategic Planning &,- 050 &, 206 &,- 028 &,- 244 &, 808 \\
& Costumer and Market Focus &, 341 &, 184 &, 214 & 1,855 &, 068 \\
& MAKM &, 212 &, 197 &, 126 & 1,075 &, 286 \\
& Human Resources Focus &, 108 &, 148 &, 085 &, 729 &, 468 \\
& Process Management &, 101 &, 173 &, 070 &, 585 &, 560 \\
& Bussiness result &, 223 &, 178 &, 148 & 1,251 &, 215 \\
\hline
\end{tabular}

Tabel 10

ANOVA

\begin{tabular}{|c|c|c|c|c|c|c|}
\hline \multicolumn{2}{|c|}{ Model } & \multirow{2}{*}{$\begin{array}{r}\begin{array}{c}\text { Sum of } \\
\text { Squares }\end{array} \\
185,206\end{array}$} & df & Mean Square & \multirow{2}{*}{$\begin{array}{l}\mathbf{F} \\
9,399\end{array}$} & \multirow{2}{*}{$\begin{array}{l}\text { Sig. } \\
\text {,000(a) }\end{array}$} \\
\hline 1 & Regression & & 7 & 26,458 & & \\
\hline & Residual & 208,318 & 74 & 2,815 & & \\
\hline & Total & 393,524 & 81 & & & \\
\hline
\end{tabular}

atau 2,143 > 1,988 jadi $\mathrm{H}_{0}$ ditolak, kesimpulannya kriteria leadership berpengaruh dalam peningkatan produktivitas PT PJB UP Gresik.

\section{Strategic Planning $\left(\mathrm{X}_{2}\right)$}

Berdasarkan perhitungan diperoleh t hitung sebesar -0,244 lebih kecil dari t tabel sebesar 1,998. Dapat diketahui bahwa $\mathrm{t}$ hitung $<\mathrm{t}$ tabel atau $-0,244<1,988$ jadi $\mathrm{H}_{0}$ diterima, kesimpulannya kriteria strategic planning tidak berpengaruh dalam peningkatan produktivitas PT PJB UP Gresik.

\section{Costumer and Market Focus $\left(\mathrm{X}_{3}\right)$}

Berdasarkan perhitungan diperoleh $\mathrm{t}$ hitung sebesar 1,855 lebih kecil dari $t$ tabel sebesar 1,998. Dapat diketahui bahwa $\mathrm{t}$ hitung $<\mathrm{t}$ tabel atau 1,855 $<1,988$ jadi $\mathrm{H}_{0}$ diterima, kesimpulannya kriteria costumer and market focus tidak berpengaruh dalam peningkatan produktivitas PT PJB UP Gresik.

4. Measurement, Analysis, and Knowledge Management $\left(\mathrm{X}_{4}\right)$

Berdasarkan perhitungan diperoleh $\mathrm{t}$ hitung sebesar 1,075 lebih kecil dari t tabel sebesar 1,998. Dapat diketahui bahwa $\mathrm{t}$ hitung $<\mathrm{t}$ tabel atau $1,075<1,988$ jadi $\mathrm{H}_{0}$ diterima, kesimpulannya kriteria measurement, analysis and knowledge management tidak berpengaruh dalam peningkatan produktivitas PT PJB UP Gresik.

5. Human Resources Focus $\left(\mathrm{X}_{5}\right)$
Berdasarkan perhitungan diperoleh $\mathrm{t}$ hitung sebesar 0,729 lebih kecil dari t tabel sebesar 1,998. Dapat diketahui bahwa $\mathrm{t}$ hitung $<\mathrm{t}$ tabel atau $0,729<1,988$ jadi $\mathrm{H}_{0}$ diterima, kesimpulannya kriteria human resources focus tidak berpengaruh dalam peningkatan produktivitas PT PJB UP Gresik.

6. Focuss Management $\left(\mathrm{X}_{6}\right)$

Berdasarkan perhitungan diperoleh $\mathrm{t}$ hitung sebesar 0,585 lebih kecil dari t tabel sebesar 1,998. Dapat diketahui bahwa thitung $<\mathrm{t}$ tabel atau 0,585 $<1,988$ jadi $\mathrm{H}_{0}$ diterima, kesimpulannya kriteria focuss management tidak berpengaruh dalam peningkatan produktivitas PT PJB UP Gresik.

7. Business Result $\left(\mathrm{X}_{7}\right)$

Berdasarkan perhitungan diperoleh $\mathrm{t}$ hitung sebesar 1,251 lebih kecil dari t tabel sebesar 1,998. Dapat diketahui bahwa $\mathrm{t}$ hitung $<\mathrm{t}$ tabel atau 1,251 $<1,988$ jadi $\mathrm{H}_{0}$ diterima, kesimpulannya kriteria $\mathrm{Busi}$ ness Result tidak berpengaruh dalam peningkatan produktivitas PT PJB UP Gresik.

\section{Uji F (Uji Simultan)}

Uji F digunakan untuk menguji pengaruh variabel independen (X) secara bersama-sama terhadap variabel dependen (Y), dengan menggunakan tingkat signifikansi 0,05 , df1 $=\mathrm{k}-1$ atau $8-1=7$, dan df2 $=$ n-k atau 82-8 $=74(\mathrm{k}$ adalah jumlah 
variabel dan n adalah jumlah sampel), hasil yang didapat $\mathrm{F}$ tabel adalah 2,140 sedangkan untuk $\mathrm{F}$ hitung didapat 9,399.

Berdasarkan hasil analisis dan dapat dilihat pada tabel 10 dapat diketahui bahwa $\mathrm{F}$ hitung $(9,399)>$ F tabel $(2,140)$ jadi hipotesis nol ditolak dan dapat ditarik kesimpulan bahwa Malcolm Baldrige Criteria memiliki pengaruh secara simultan atau bersama-sama dalam peningkatan produktivitas di PT PJB UP Gresik.

\section{KESIMPULAN}

Berdasarkan hasil analisis data yang telah diuraikan dalam penelitian ini dan berdasarkan rumusan masalah serta tujuan penelitian dapat disimpulkan bahwa, sebagai berikut:

1. Penerapan Malcolm Baldrige Criteria di PT PJB UP Gresik dinilai telah berhasil, hal ini diindikasikan bahwa memiliki tingkat efektivitas yang baik (efektif), artinya tiap kriteria pada Malcolm Baldrige memiliki keefektivan yang baik dalam peningkatan produktivitas di PT PJB UP Gresik. Penilaian prosentase efektivitas secara umum dengan menggunakan Malcolm Baldrige Criteria adalah PT PJB UP Gresik menunjukkan permulaan pendekatan (approach) yang sistematis dalam menjawab persyaratan dasar dari item leadership, strategic planning, costumer \& market focus, MAKM, human resources focus, process management dan business result. Tetapi terdapat gap cukup besar dalam pendekatan (approach) dan pelaksanaan (deployment) dibeberapa kriteria.

2. Berdasarkan hasil analisis regresi linear berganda didapatkan bahwa pengaruh penerapan Malcolm Baldrige Criteria dalam peningkatan produktivitas di PT PJB UP Gresik secara simultan atau secara bersama-sama memiliki pengaruh yang signifikan sedangkan secara parsial hanya kriteria leadership saja yang mempunyai pengaruh positif dalam pening- katan produktivitas PT PJB UP Gresik. Selain dari kriteria tersebut tidak mempunyai pengaruh yang signifikan dalam peningkatan produktivitas PT PJB UP Gresik.

\section{REKOMENDASI}

Berdasarkan hasil analisis, pembahasan dan kesimpulan penelitian, maka saran-saran dari peneliti yang dapat dijadikan referensi adalah:

1. Penerapan Malcolm Baldrige Criteria dinilai efektif, namun perusahaan hendaknya meningkatkan pengembangan terhadap system pengukuran produktivitas perusahaan yang lebih baik sesuai dengan kondisi perusahaan dan meningkatkan wawasan serta keahlian pegawai mengenai sistem yang telah atau akan dikembangkan diperusahaan.

2. Membangun tim yang kuat guna melaksanakan beberapa pendekatan metode sistematis yang sesuai untuk melaksanakan proses tujuh kriteria serta melaksanakan dan mengevaluasi organisasi secara konsisten. Pelibatan tim dalam pengembangan dan penyebaran perencanaan strategis. Pendekatan untuk menciptakan nilai bagi pelanggan. Strategi dan program secara terus menerus untuk meningkatkan loyalitas pelanggan. Selain itu Malcolm Baldrige Criteria tidak hanya digunakan untuk mengukur produktivitas perusahaan saja, melainkan Malcolm Badrige Criteria juga dapat digunakan untuk mengukur kinerja perusahaan untuk menjadi perusahaan unggul atau excellence.

3. Penelitian selanjutnya diharapkan dapat meneliti obyek/perusahaan lain yang lebih luas dan terbaru atau pun hal lain yang memiliki hubungan dengan peningkatan produktivitas perusahaan, diantaranya yakni mengenai alat bantu pengukuran produktivitas yang lebih baik dan sesuai dengan kondisi perusahaan di Indonesia sehingga lebih mudah diterapkan di dalam perusahaan. 


\section{REFERENSI}

Arif, Fauzi, 2005, Analisa Persepsi Manajer Perusahaan Terhadap Indikator-Indikator Pengukuran Kinerja Dalam Malcolm Baldrige Criteria, Jurnal Eksekutif Vol.2 No.2, Jakarta

Arikunto, Suharsini, 2002, Prosedur Penelitian Suatu Pendekatan Praktek, Rinekacipta, Yogyakarta

Ayuningtyas, Dumilah. Dkk, 2005 , Penelitian Mutu Rumah Sakit Tugu Ibu Dengan MBNQA Tahun 2005, JMPK Vol.8 No.4, UI Jakarta

Bungawati , Tria Suri , 2010 , Pengaruh Penerapan Malcolm Baldrige National Quality Award Terhadap Peningkatan Kinerja Perusahaan (Studi Kasus PT.PERTAMINA persero), Univ.Pendidikan Indonesia,Jakarta

Britannica, The New Encyclopedia, Volume 20, 2007

Gaspersz,Vincent, 2007, Organizational Excellence, Gramedia Pustaka Utama,Jakarta

2007, GE Way and Malcolm Baldrige Criteria for Performance Excellence, Gramedia Pustaka Utama,Jakarta

Ghozali, Imam, 2009, Aplikasi Analisa Multivariate Dengan Program SPSS, Edisi I, Badan PenerbitUNDIP Semarang

Handoko, Hani, 1999, Dasar-Dasar Manajemen Produksi dan Operasi, BPFE, Yogyakarta

Muchdarsyah, Sinungan, 1987, Produktivitas Apa dan Bagaimana, Aksara Persada Press, Jakarta

Mulyono, Sri, 2003, Statistika Untuk Ekonomi edisi kedua, Lembaga Penerbit FE UI, Jakarta

Muslih, Imam, 2007, Analisis Pengaruh Penerapan Total Quality Management Terhadap Peningkatan Kinerja Karyawan Operasional Non Teknik PT PJB UP Gresik, Universitas Muhammadiyah Gresik, Gresik

NIST, 2010, Baldrige Performance Excellence Program, American Society for Quality, America

Priyatno, Dwi, 2007, Mandiri Belajar SPSS Untuk Analisis Data \& Uji Statistik,Penerbit Andy, Jakarta

Priyatno, Duwi, 2010, Teknik Mudah Dan Cepat Melakukan Analisis Data Penelitian dengan SPSS, Penerbit Gava Media, Yogyakarta

PT PJB, Statistik Perusahaan 2005-2009, Surabaya , Laporan Tahunan 2010 Annual Report PJB, Surabaya 2008, Profil Perusahaan Pembangkit Jawa Bali, Humas dan COMDEV PT PJB, Surabaya 
Sadikin, Iskandar, 2005, Bunga Rampai Kriteria Bisnis Malcolm Baldrige National Quality Award (MBNQA) , Telkom Training Center,Surabaya

Sedarmayanti, 2009, Sumber Daya Manusia dan Produktivitas Kerja , CV.Mandar Maju , Bandung

Semen Gresik, 2010, Integrasi Sistem Manajemen Untuk Mencapai Bisnis Ekselen, PT Semen Gresik Tbk, Gresik

Sugiyono, 2008, Metode Penelitian Bisnis, CV.Alfabeta , Bandung

Sukaris, 2009, Analisis Data Statistik dengan SPSS, Prodi Manajemen FE UMG, Gresik

Steers, Richard.M, 1985, Efektivitas Organisasi,Erlangga , Jakarta

Tjiptono, Fandi, 2003, Total Quality Management, Penerbit Andi , Yogyakarta

Umar, Husein, 2005, Evaluasi Kinerja Perusahaan, Gramedia Pustaka Utama, Jakarta

Utami, Cristina Whidya, 2002, Peningkatan Nilai Perusahaan Melalui Perbaikan Produktivitas dan Kualitas Pada Sektor Jasa Sebuah Analisis Konseptual, Jurnal Manajemen Vol.4 No.1, UWK Surabaya

Welch, Jack, 2004, Welch's Seven-Point Program for Management by Leadership, McGraw-Hill Inc, New York

Yamit, Zulian, 2003 , Manajemen Produksi dan Operasi, Ekonisia FE UII, Yogyakarta 